\title{
THE IMPACT OF HUMAN RESOURCES MANAGEMENT PRACTICES ON JOB PERFORMANCE: THE CASE OF NURSES AT SILOAM LIPPO VILLAGE HOSPITAL
}

\author{
Ditta Amelia1, Rosdiana Sijabat ${ }^{2}$ \\ 1. Universitas Pelita Harapan \\ 2. Unika Atma Jaya Jakarta
}

\begin{abstract}
Human resources management has a huge role in increasing hospital performance. This study aimed to examine the effect of compensation, performance appraisal, recruitment and selection, teamwork, training, and development, on nurses' performance at the Siloam Lippo Village Hospital. A simple random sampling technique was used to collect data for this study. A questionnaire was distributed among 210 nurses at the hospital. The PLS-based Structural Equation Modeling (SEM) approach was used to check the impact of human resource management practices on job performance. The organizational commitment was used as a mediator variable on the relationship between human resource management practices and job performance. The results indicate that teamwork and organizational commitment have a significant impact on nurses' performance. This study also finds that compensation, performance appraisal, and training and development have a significant impact on organizational commitment, which leads to an increase in the nurses' performance. Organizational commitment significantly mediates the relationship between performance appraisal, teamwork, training and development, and job performance.
\end{abstract}

Keywords: Compensation, Performance appraisal, Job performance, Recruitment and selection, Teamwork, Training and development.

\section{ABSTRAK}

Manajemen sumber daya manusia memiliki peran yang besar untuk meningkatkan kinerja rumah sakit sebagai suatu organisasi. Penelitian ini bertujuan untuk mengkaji efek kompensasi, penilaian kinerja, rekrutmen dan seleksi, kerja tim, pelatihan, dan pengembangan, terhadap kinerja perawat di Rumah Sakit Siloam Lippo Village. Teknik pengambilan sampel acak sederhana digunakan untuk mengumpulkan data penelitian. Sebuah kuesioner dibagikan kepada 210 perawat di Rumah Sakit Siloam Lippo Village. Pendekatan Structural Equation Modeling (SEM) berbasis PLS digunakan untuk menganalisis dampak praktik manajemen sumber daya manusia terhadap kinjera perawat. Komitmen organisasi digunakan sebagai variabel mediator hubungan antara praktik manajemen sumber daya manusia dan prestasi kerja. Hasil penelitian menunjukkan bahwa kerjasama tim dan komitmen organisasi berpengaruh signifikan terhadap kinerja perawat. Penelitian ini juga menemukan bahwa kompensasi, penilaian kinerja, dan pelatihan dan pengembangan memiliki pengaruh yang signifikan terhadap komitmen organisasi, yang menyebabkan peningkatan kinerja perawat. Komitmen organisasi secara signifikan memediasi hubungan antara penilaian kinerja, kerja tim dan pelatihan dan pengembangan, dan kinerja pekerjaan.

Kata kunci: Kerja sama tim, Kompensasi, Pelatihan dan pengembangan, Penilaian kinerja, Prestasi kerja, Rekrutmen dan seleksi. 


\section{INTRODUCTION}

Changes in technology encourage increasingly fierce competition in almost all lines of business organizations. To deal with the increasingly fierce competition, every organization, not to mention organizations in the service sector, needs human resources who have the best competencies in order to be able to provide optimal services so that they can compete well (Morley \& Cashel, 2017; Lizote, Verdinelli \& Nascimento, 2017). Various strategies can be carried out to face increasingly intense business competition, especially in the hospital sector, given the increasing number of hospitals in Indonesia (Muntazeri \& Indrayanto, 2018). The growth of public hospitals in Indonesia from 2012 to April 2018 is not as fast as private hospitals' growth. The average growth of public hospitals is $0.02 \%$, while private hospitals are growing at $1.29 \%$. This growth rate is an indication that private hospitals play a significant role in Indonesia's health industry (https://www.persi.or.id, retrieved on $25 / 07 / 2018$ ).

The era of globalization and economic and business integration has led to the easier mobilization of labor, including the health sector workforce. The existence of these conditions is a challenge that needs to be faced because it is followed by the tendency to enter foreign health sector workers into Indonesia to work and provide health services (Maryadi et al., 2018). The Ministry of Manpower reported that the number of foreign workers in 2017 reached 126 thousand workers, increasing 69.85 percent from the end of 2016 where there were 74,813 people (Maryadi et al., 2018).

The positive side of labor migration is the opportunity to transfer technology over to the health sector (Amah, 2019). Nevertheless, in addition to the positive side, such conditions can also threaten the Indonesian health sector workers who are less competent because external health workers' migration can reduce employment opportunities for Indonesian health workers. The existence of the tendency towards increasingly fierce competition in the health sector needs to be addressed wisely and vigilantly with appropriate strategies, adequate arrangements, and increasing Indonesian health workers' competence and quality of work standards.

This phenomenon is certainly a concern for hospital management who are required to evaluate their workforce. For example, the shift in treatment patterns for the elite who tend to have health services and treatment overseas (Hameed \& Mohamed, 2016; Amah, 2019). For this reason, so that national hospitals, especially private hospitals, can compete competitively, hospitals need to implement several strategies. One of them is the practice of human resource management that can increase competency to support organizational performance. The success of an organization is also determined by the quality of the employees working in the organization. Therefore, organizational culture can function optimally with organizational members who have the same perceptions and goals towards the organizational culture and participation (Amah, 2019; Vinesh, 2014). Thus, one crucial aspect of competition in the hospital sector is the services provided by qualified nurses.

One group of hospitals with management and private ownership is the Siloam Hospitals Group (Siloam). In 2015, Siloam operated 20 hospitals after starting business in 1996 under the name PT. Sentralindo Wirasta. In 2017 there were a total of 33 Siloam hospital branches spread throughout Indonesia. Within the first three months, Siloam Hospitals Group officially opened a new branch, so there are now in total, Siloam 34 branches.

Human resource management (HRM) practice consists of recruitment and selection, compensation and rewards, performance appraisal, collaboration, and training and development (Hameed \& Mohamed, 2016). Recruitment and selection have become increasingly important as organizations increasingly consider their workforce as a source of competitive advantage. It assumes that worker selection occurs not only to replace employees or increase numbers but also aims to place workers who can perform at a higher level and show commitment. This 
role is presented as a rational planned activity and consists of sequential interrelated phases in resourcing employees. The recruitment and voting process may come in four stages: defining needs, planning recruitment campaigns, attracting candidates, and selecting candidates (Hameed \& Mohamed, 2016).

Meanwhile, the compensation and award scheme is designed based on the philosophy of compensation and the strategies contained in the form of policies, guiding principles, structures, and procedures, which are designed and managed to provide and determine the right types of staff compensation such as salary increases, benefits, and other forms of compensation (Vinesh, 2014). This results from measuring work values, designing and maintaining salary structures, payment by performance results, competence, and skills, and employee benefits. Compensation has a motivational effect and has a compensation structure where employees who perform better are paid more than employees who perform averagely. Hence, the importance of job performance improvement is seen. Performance appraisal is an indispensable tool for an organization because its information is beneficial in making decisions about promotion, transfer, training, and development. Performance assessment can increase employee commitment and job satisfaction.

Another vital part of HRM practices is teamwork. According to Morley (2017), teamwork is a strategy that can improve the performance of individuals and organizations but needs to be maintained from time to time. Organizations need to look at strategies to improve performance in light of an increasingly competitive environment. Top managers must have the vision to introduce teamwork activities within the organization, sensitivity to mutual care, and courage to play an essential part in decision making. Teamwork is relevant to training and development.

Referring to Elnaga and Imran (2013), training and development includes every effort to increase current or future employees by increasing employee capabilities through learning, usually by changing employee attitudes or improving skills and knowledge. While training is seen as a process of instilling special skills and development, it is a learning opportunity designed to help employees grow. According to Armstrong (2010) and Vinesh (2014), training is a formal modification and systematic behavior through learning that occurs due to education, teaching, development, and planned experience.

Organizational commitment plays a significant role in HRM practices. Organizational commitment is a feeling of employees' psychological or physical attachment to the organization where they work (Lizote, Verdinelli, \& Nascimento, 2017). Meanwhile, Luthans (2011) explains that organizational commitment can be defined as (a) a strong desire to remain as a member of a particular organization, (b) the desire to urge highlevel efforts on behalf of the organization, (c) and beliefs that define and accept the values and goals of the organization. Organizational commitment is assessed by organizational performance and work performance. Organizational performance is a broader indicator that can include productivity and quality, consistency, effectiveness, efficiency, and other factors. Organizational performance continues to be a contentious issue in management research circles (Hameed \& Mohamed, 2016). This is demonstrated by equating performance with the well-known $3 \mathrm{E}$, economy, efficiency, and effectiveness of particular activity programs. According to Pfeffer (2010), work performance is the quality of work achieved by an employee in carrying out his/her duties following the given responsibilities (Pradhan \& Jena, 2017). According to Muntazeri and Indrayanto, 2018), work performance is an output produced by functions or indicators of a job or profession at a specific time. Work performance facilitates organizational performance; thus, it is necessary to have work performance standards (Sahoo \& Mishra, 2012).

\section{METHOD}

This research is quantitative with a causality design (causal relationship). 
Quantitative research emphasizes the analysis of quantitative data (numbers) collected through measurement procedures and processed by statistical analysis methods (Azwar, 2016; Bryman, 2016). Causal design can be useful for measuring the relationships between research variables as well as for analyzing how a variable affects other variables (Gilardi, 2012; Sekaran \& Bougie, 2016). The dependent variable in this study is job performance, while the independent variable is Human Resource Management practices, and the mediating variable is Organizational Commitment (Figure 1).

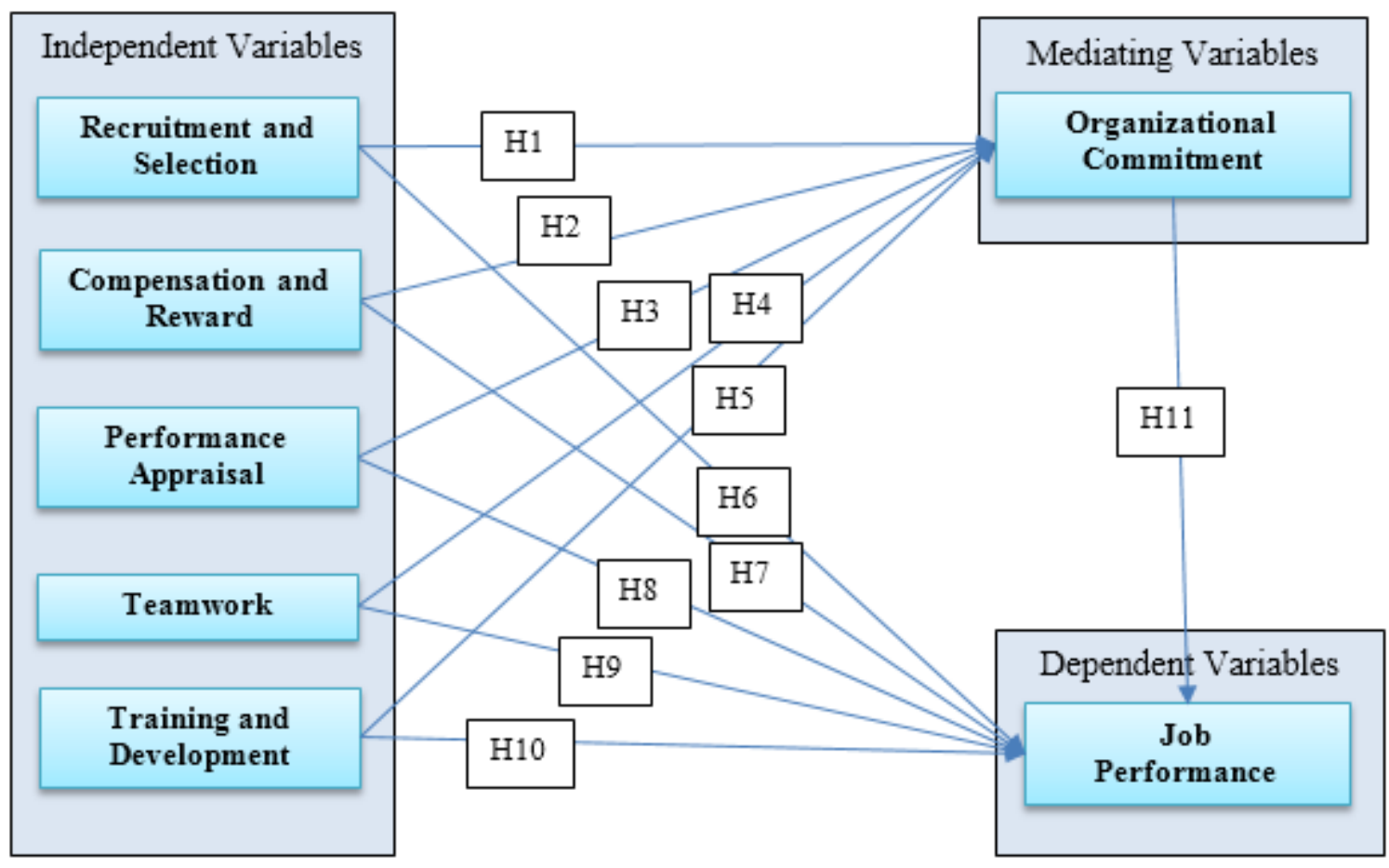

Figure 1. Research Model

This study used primary data and secondary data. Primary data was collected through questionnaires filled by nurses who are working at Siloam Lippo Village Hospital. The total number of nurses at the hospital is 400 , and the respondents in this study were 210 . The respondents were selected using simple random sampling, which is sampling randomly selected from the population regardless of the society's strata (S (Sugiyono, 2016; Sekaran \& Bougie, 2016).

This sampling technique was chosen because the respondents in this study were homogeneous, namely, only in the nurse division. The questions in the questionnaire consist of two parts. The pretest was conducted on 30 respondents who were nurses at Siloam Hospital. The purpose of this pretest is to see the consistency and accuracy of the research instrument. If the value of the loading factor value $<0.7$ and the value of discriminant validity $<0.5$, then the item on the variable under study is declared invalid. Simultaneously, the variable is reliable if the Cronbach alpha value and composite reliability are 0.7 (Hair et al., 2014).

The researcher revised several instruments that had met the validity and reliability requirements by not using (dropping out) invalid statement items. The first part contains questions about the respondents' demographic information, including age, gender, and educational background. The second part of the questionnaire contains items which are indicators of each of the variables studied, namely recruitment and selection (4 questions), compensation and rewards (7 questions), performance appraisal (5 questions), teamwork (8 questions), training and development (3 questions), job performance (25 questions), and 
organizational commitment (6 questions). The measure for recruitment and selection, compensation and rewards, performance appraisal, teamwork, training, and development were mainly adapted from Hameed and Mohamed (2016) and Morley and Cashel (2017). While measurements for job performance and organizational commitment were based on previous studies, among others Lizote, Verdinelli and Nascimento (2017); Hameed and Mohamed (2016) and Pradhan and Jena (2017). The 5 - point Likert-type scale was used in the questions. The scale used was 1 (strongly disagree), 2 (disagree), 3 (neutral), 4 (agree), and 5 (strongly agree).

The structural equation model (SEM) is used to analyze the complicated relationship between human resources management practices, job performance, and organizational commitment. SEM is widely used in the behavioral sciences in which factor analysis and regression or path analysis are combined (Xiong, Skitmoren \& Xia, 2015). SEM is part of a covariance-based statistical methods technique for analyzing the causal relationship among latent constructs (Kline, 2015). In this study, SEM analysis is undertaken by using the Partial Least Square (PLS) approach. SEM is employed to examine the complicated relationship between three latent variables adapted from various literature. These variables are human resources management practices, job performance, and organizational commitment; the total overall measurement items in the three latent variables are 58 construct items (see Appendix 1).

\section{The Validity of the Construct}

Construct validity is evaluated based on two convergent validity and discriminant validity (Flake, Pek \& Hehman, 2017). Convergent validity tests in PLS with reflective indicators are assessed based on loading factors (correlation between component scores and construct scores), which are indicators that measure the construct. The rule of thumb used for convergent validity is the factor loading $>0.7$, communality $>0.5$ and average variance extracted (AVE) $>0.5$
(Hair et al., 2014; Abdillah \& Jogiyanto, 2015: 195). The research model has sufficient discriminant validity if the root AVE for each construct is greater than the correlation between constructs and other constructs in the research model (Abdillah \& Jogiyanto, 2015).

As summarized in Table 1, the value of the loading factor constructs of organizational commitment and compensation and reward variables, all of which have a value of loading factor $>0.7$, so that all constructs are concluded to be valid. In the performance appraisal variable, there are two invalid constructs, namely PA2 and PA5. There are nine invalid items in the job performance variable (JP1, JP2, JP4, JP6, JP9, JP13, JP15, JP19, and JP21).

In recruitment and teamwork variables, each of them has one invalid construct, R4, and T4. There are two invalid statement items in the training and development variables, namely, construct TD1 and TD4. All invalid constructs are dropped and not used as constructs. The discriminant validity test in Table 1 also shows that the AVE of all latent variables> 0.5 , so it is concluded that each variable is valid. Cronbach's alpha value and composite reliability on each variable show a value greater than 0.7 . The result shows that all the constructs of all the research questions have been declared reliable.

\section{RESULT}

\section{Profile of Respondents}

Respondents aged 26-30 were the majority of the respondents $(37.1 \%)$, then most were aged between $31-35$ years $(36.2 \%)$, then $<25$ years $(15.2 \%)$, then 36 40 years $(6.7 \%)$, and lastly> 40 years $(4.8 \%)$. According to the characteristics of the education level, most of them were undergraduates (64.3\%), Diploma 1 Diploma 3 graduates (21.9\%), Master degree graduates $(7.5 \%)$, and high school graduates $(5.7 \%)$, only $5 \%$ had a doctoral degree. Of 201 respondents, $66.7 \%$ (140) were women, and $33.3 \%$ (70) were men.

\section{Analysis with Partial Least Square (PLS)}

The inner model and outer model are analyzed in the SEM (Wong, 2013). The outer model analysis ensures that the 
measurement model used is feasible to be measured by fulfilling the assumptions of validity and reliability. The convergent validity test can be seen from the magnitude of the loading factor value.
While the discriminant validity test can be seen from the AVE value. While the reliability test can be seen from the size of the composite reliability value as presented in the following table.

Table 1. Outer Model Analysis

\begin{tabular}{|c|c|c|c|c|}
\hline Variable & Code & Loading Factor & AVE & Composite Reliability \\
\hline \multirow{3}{*}{ Recruitment and Selection } & R1 & 0.914 & 0.834 & 0.938 \\
\hline & R2 & 0.916 & & \\
\hline & R3 & 0.911 & & \\
\hline \multirow[t]{7}{*}{ Compensation/ Reward } & C1 & 0.802 & 0.612 & 0.917 \\
\hline & C2 & 0.797 & & \\
\hline & C3 & 0.810 & & \\
\hline & C4 & 0.737 & & \\
\hline & C5 & 0.814 & & \\
\hline & C6 & 0.736 & & \\
\hline & C7 & 0.778 & & \\
\hline \multirow[t]{3}{*}{ Performance Appraisal } & PA1 & 0.875 & 0.770 & 0.910 \\
\hline & PA3 & 0.889 & & \\
\hline & PA4 & 0.869 & & \\
\hline \multirow[t]{6}{*}{ Teamwork } & T1 & 0.791 & 0.669 & 0.924 \\
\hline & T2 & 0.805 & & \\
\hline & T3 & 0.833 & & \\
\hline & T4 & 0.877 & & \\
\hline & T6 & 0.793 & & \\
\hline & T7 & 0.806 & & \\
\hline \multirow[t]{2}{*}{ Training and Development } & TD2 & 0.924 & 0.832 & 0.808 \\
\hline & TD3 & 0.900 & & \\
\hline \multirow[t]{6}{*}{ Organizational Commitment } & OC1 & 0.894 & 0.775 & 0.954 \\
\hline & OC2 & 0.883 & & \\
\hline & OC3 & 0.893 & & \\
\hline & OC4 & 0.875 & & \\
\hline & OC5 & 0.834 & & \\
\hline & OC6 & 0.902 & & \\
\hline \multirow[t]{16}{*}{ Job Performance } & JP3 & 0.768 & 0.617 & 0.962 \\
\hline & JP5 & 0.745 & & \\
\hline & JP7 & 0.770 & & \\
\hline & JP8 & 0.853 & & \\
\hline & JP10 & 0.745 & & \\
\hline & JP11 & 0.777 & & \\
\hline & JP12 & 0.831 & & \\
\hline & JP14 & 0.718 & & \\
\hline & JP16 & 0.851 & & \\
\hline & JP17 & 0.736 & & \\
\hline & JP19 & 0.765 & & \\
\hline & JP20 & 0.725 & & \\
\hline & JP22 & 0.829 & & \\
\hline & JP23 & 0.817 & & \\
\hline & JP24 & 0.789 & & \\
\hline & JP25 & 0.823 & & \\
\hline
\end{tabular}

Source: Result from Smart PLS 3.0.

The convergent validity test can be seen from the magnitude of the value of loading factors in each item indicator, which in each item has a value of loading factor > 0.7, which means that all indicators are declared valid and fulfill the convergent validity test. The AVE values indicate that all indicators are valid, which have AVE values that are higher than 0.5. Reliability test results show that all variables have a composite reliability value of 0.7. Thus all constructs are reliable 
(Wong, 2013; Hair et al, 2014). The inner evaluation model is done by looking at the magnitude of the $R$ Square value, as presented in the following table.

Table 2. R Square Obtained

\begin{tabular}{lcc}
\hline $\begin{array}{l}\text { Dependent } \\
\text { Variable }\end{array}$ & R Square & $\begin{array}{l}\text { R Square } \\
\text { Adjusted }\end{array}$ \\
\hline $\begin{array}{l}\text { Organizational } \\
\text { Commitment } \\
\text { Job }\end{array}$ & 0.856 & 0.849 \\
Performance & 0.985 & 0.984 \\
Source: Result from Smart PLS 3.0.
\end{tabular}

The value of $R$ square is 0.856 and 0.985 . Thus, it can be said that the independent variable consisting of recruitment and selection, compensation and rewards, performance appraisal, teamwork, and training ad development can explain $85.6 \%$ of organizational commitment variables. This study also shows that recruitment and selection, compensation and rewards, performance appraisal, teamwork and training, and development and organizational commitment can explain job performance variables by $98.5 \%$. In contrast, other variables outside the model explain the rest.

Table 3. Path Coefficient

\begin{tabular}{|c|c|c|c|c|c|c|}
\hline No. & Hypotheses & $\begin{array}{l}\text { Original } \\
\text { Sample } \\
\text { (0) }\end{array}$ & $\begin{array}{l}\text { Sample } \\
\text { Mean } \\
\text { (M) }\end{array}$ & $\begin{array}{l}\text { Standard } \\
\text { Deviation } \\
\text { (STDEV) }\end{array}$ & $\begin{array}{l}\text { T Statistics } \\
\text { (|O/STDEV } \mid)\end{array}$ & $\begin{array}{l}\mathbf{P} \\
\text { Value }\end{array}$ \\
\hline $\mathrm{H} 1$ & $\begin{array}{l}\text { Recruitment and Selection } \rightarrow \\
\text { Organizational Commitment }\end{array}$ & 0.196 & 0.202 & 0.112 & 1.748 & 0.083 \\
\hline $\mathrm{H} 2$ & $\begin{array}{l}\text { Compensation/ Reward } \rightarrow \\
\text { Organizational Commitment }\end{array}$ & 0.220 & 0.226 & 0.108 & 2.040 & 0.044 \\
\hline H3 & $\begin{array}{l}\text { Performance Appraisal } \rightarrow \\
\text { Organizational Commitment }\end{array}$ & 0.161 & 0.163 & 0.071 & 2.252 & 0.026 \\
\hline $\mathrm{H} 4$ & $\begin{array}{l}\text { Teamwork } \rightarrow \text { Organizational } \\
\text { Commitment }\end{array}$ & 0.244 & 0.236 & 0.090 & 2.724 & 0.008 \\
\hline H5 & $\begin{array}{l}\text { Training and Development } \rightarrow \\
\text { Organizational Commitment }\end{array}$ & 0.208 & 0.198 & 0.070 & 2.987 & 0.004 \\
\hline $\mathrm{H} 6$ & $\begin{array}{l}\text { Recruitment and Selection } \rightarrow \\
\text { Job Performance }\end{array}$ & 0.161 & 0.165 & 0.031 & 5.172 & 0.000 \\
\hline $\mathrm{H} 7$ & $\begin{array}{l}\text { Compensation/ Reward } \rightarrow \\
\text { Job Performance }\end{array}$ & 0.116 & 0.120 & 0.039 & 2.987 & 0.004 \\
\hline $\mathrm{H} 8$ & $\begin{array}{l}\text { Performance Appraisal } \rightarrow \\
\text { Job Performance }\end{array}$ & 0.154 & 0.154 & 0.025 & 6.088 & 0.000 \\
\hline H9 & $\begin{array}{lll}\text { Teamwork } & \rightarrow & \text { Job } \\
\text { Performance } & & \end{array}$ & 0.361 & 0.360 & 0.046 & 7.899 & 0.000 \\
\hline $\mathrm{H} 10$ & $\begin{array}{l}\text { Training and Development } \rightarrow \\
\text { Job Performance }\end{array}$ & 0.114 & 0.113 & 0.023 & 4.855 & 0.000 \\
\hline $\mathrm{H} 11$ & $\begin{array}{l}\text { Organizational Commitment } \\
\rightarrow \text { Job Performance }\end{array}$ & 0.184 & 0.179 & 0.036 & 5.111 & 0.000 \\
\hline
\end{tabular}

Source: Result from Smart PLS 3.0.

Table 4. Indirect Effect

\begin{tabular}{lccccc}
\hline Hypotheses & $\begin{array}{l}\text { Original } \\
\text { Sample } \\
(\mathbf{O})\end{array}$ & $\begin{array}{l}\text { Sample } \\
\text { Mean } \\
(\mathbf{M})\end{array}$ & $\begin{array}{l}\text { Standard } \\
\text { Deviation } \\
\text { (STDEV) }\end{array}$ & $\begin{array}{l}\text { T Statistics } \\
(\mid \mathbf{O} / \text { STDEV|) }\end{array}$ & $\begin{array}{l}\mathbf{P} \\
\text { Value }\end{array}$ \\
\hline $\begin{array}{l}\text { Compensation/ Reward } \rightarrow \\
\text { Organizational Commitment }\end{array}$ & 0.040 & 0.041 & 0.022 & 1.809 & 0.073 \\
$\begin{array}{l}\rightarrow \text { Job Performance } \\
\begin{array}{l}\text { Oerformance Appraisal } \rightarrow \\
\text { Organizational Commitment }\end{array}\end{array}$ & 0.030 & 0.029 & 0.014 & 2.143 & 0.035 \\
$\begin{array}{l}\text { Job Performance } \\
\text { Recruitment and Selection } \rightarrow \\
\text { Organizational Commitment }\end{array}$ & 0.036 & 0.037 & 0.023 & 1.552 & 0.124 \\
$\begin{array}{l}\rightarrow \text { Job Performance } \\
\text { Teamwork } \rightarrow \text { Organizational }\end{array}$ & 0.045 & 0.042 & 0.018 & 2.501 & 0.014
\end{tabular}




\begin{tabular}{llllll}
\hline \hline Hypotheses & $\begin{array}{l}\text { Original } \\
\text { Sample } \\
(\mathbf{O})\end{array}$ & $\begin{array}{l}\text { Sample } \\
\text { Mean } \\
(\mathbf{M})\end{array}$ & $\begin{array}{l}\text { Standard } \\
\text { Deviation } \\
(\mathbf{S T D E V})\end{array}$ & $\begin{array}{l}\text { T Statistics } \\
(|\mathbf{O} / \mathbf{S T D E V}|)\end{array}$ & $\begin{array}{l}\mathbf{P} \\
\text { Value }\end{array}$ \\
\hline $\begin{array}{l}\text { Commitment } \rightarrow \text { Job } \\
\text { Performance }\end{array}$ & & & & & \\
$\begin{array}{l}\text { Training and Development } \rightarrow \\
\text { Organizational Commitment } \\
\rightarrow \text { Job Performance }\end{array}$ & 0.038 & 0.035 & 0.014 & 2.707 & 0.008 \\
\hline
\end{tabular}

The PLS analysis carried out with the Smart PLS version 3 program produced the PLS Algorithm model and PLS Bootstrapping, as presented in the following figure below. The PLS Algorithm image explains the loading factor values of each item and the structural coefficient path value accompanied by an explanation of the value of $R$ square.

The PLS Bootstrapping image describes the statistical value of $t$ that can be used in analyzing the significance level of influence between variables.

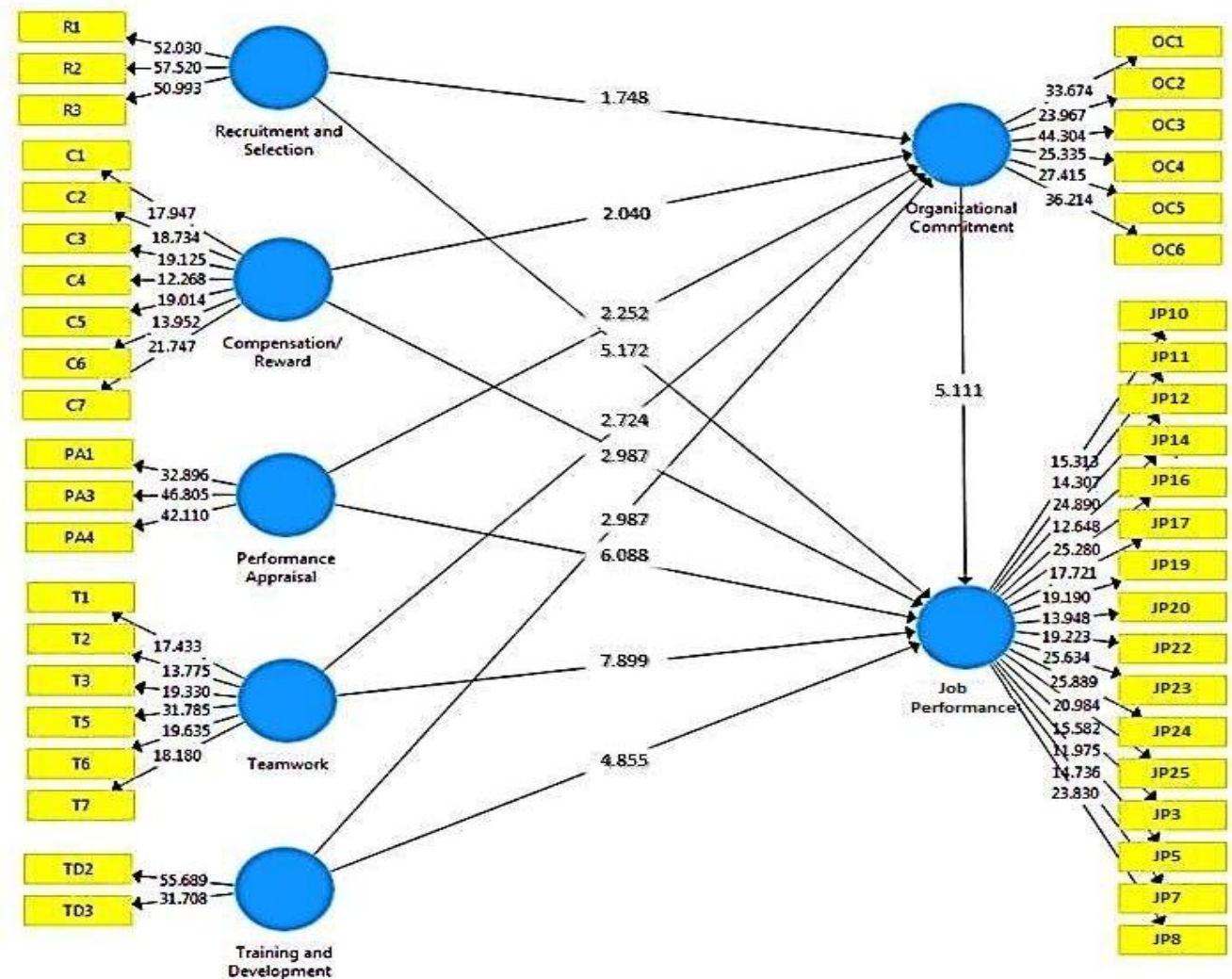

Figure 2. Result of the Structural model

\section{DISCUSSION}

The overall results from the analysis of structural models reveals that one of the five human resources management practices, i.e., recruitment and selection, acts as an insignificant predictor of organizational commitment. This indicates that the right nurse selection, even with adequate qualifications and traits, does not increase their commitment to remain members of the organization (Vinesh, 2014; Flake, Pek \& Hehman 2017).
The results of subsequent studies determined that compensation and rewards had a significant effect on organizational commitment. This reveals that hospitals' compensation and reward policies can encourage employees, namely nurses, to increase their productivity, which leads to improving organizational commitment (Morley \& Cashel, 2017). Furthermore, it was identified that the performance appraisal had a significant effect on organizational commitment. This finding explains that 
performance appraisal can motivate hospitals to increase nurse productivity and performance. So, it is recommended that the performance appraisal mechanism be appropriately managed; therefore, producing better organizational commitment (Lizote, Verdinelli, \& Nascimento, 2017).

On the other hand, teamwork had a significant impact on organizational commitment. This may be due to strong incentives for individuals who, in turn, must support their team members by sharing knowledge about procedures in all departments. Training and development proved significant and contributed to organizational commitment in the hospital. Hospitals' training and development is a platform for nurses to capture and share work knowledge that can be used to improve their individual, organizational commitment, which can result in increased job performance (Hamed, 2016; Vinesh, 2014).

The results of other studies, namely, recruitment and selection, proved significant for job performance. This shows that the implementation of recruitment and selection at Siloam Lippo Village Hospital impacts on job performance, where the better the process is carried out, the greater the impact. Compensation and rewards have a significant effect on job performance, explaining that compensation and awards can encourage nurses to increase their productivity to increase job performance.

Furthermore, it is shown that the performance appraisal has a significant effect on job performance. Performance appraisal can increase nurse productivity. As evidenced every year, all Siloam Lippo Village hospital employees are asked to fill out Key Performance Indicators, these indicators can encourage employees to improve their performance to produce the organization's expected job performance. Teamwork proved to have a significant impact on job performance. On the other hand, training and development also proved significant and contributed to job performance in hospitals. Training and development has been carried out at Siloam Lippo Village Hospital with a further education program for nurses with a Diploma educational background.

Besides, Siloam Lippo Village Hospital also conducts rolling systems from one department to another and shares knowledge through presentations from each ward when acquiring new knowledge in caring for patients and the latest technology that is developing in the health sector. Organizational commitment has a significant effect on job performance. This finding proves that high employee commitment to the organization will make employees work optimally and provide the best contribution to improving job performance. Human resources management practices on job performance through organizational mediation commitment are presented in the following table.

The results show that the effect of compensation/ reward on job performance through organizational mediation commitment has a p-value of 0.073 , which is > 0.05 (Hair et al., 2014; Abdillah \& Jogiyanto, 2015). It demonstrates that organizational commitment is not a mediating variable of compensation/ reward for job performance (Pradhan, \& Jena, 2017). Related to this, the effect of performance appraisal on job performance through the mediation of organizational commitment also has a p-value of 0.035 , which is < 0.05, which means that organizational commitment variables are mediating variables of performance appraisal on job performance (Flake, Pek \& Hehman, 2017; Vinesh, 2014). The results of other analyzes show that the effect of recruitment and selection on job performance through the mediation of organizational commitment has a $p$-value of 0.124 , which is $>0.05$, which means that organizational commitment variables are not mediating recruitment and selection variables for job performance (Hameed \& Mohamed, 2016).

For the influence of teamwork on job performance through organizational mediation, commitment has a value of $p$ value 0.014 , which is $<0.05$, which means organizational commitment variables mediate variable teamwork on job performance. On the other hand, the effect of training and development on job performance through organizational 
mediation commitment has a $p$-value of 0.008 , which is $<0.05$, which means that organizational commitment variables are mediating variables of training and development on job performance (Morley \& Cashel, 2017; Hameed \& Mohamed, 2016).

\section{CONCLUSION}

Human resources management significantly improve the work performance of nurses at Siloam Lippo Village Hospital. Managerial parties are expected to appropriately practice human resources management by considering each nurse's characteristics and their levels of achievement so that it will produce output in the form of maximum performance.

\section{REFERENCES}

Abdillah, W., \& Jogiyanto. (2015). Partial Least Square (PLS) Alternatif Structural Equation Modeling (SEM) dalam Penelitian Bisnis. Yogyakarta: Andi.

Abdullah, M. (2014). Manajemen dan Evaluasi Kinerja Karyawan. Yogyakarta: Aswaja Pressindo.

Amah, O. E. (2019). Job Satisfaction and Turnover Intention Relationship: The Moderating Effect of Job Role Centrality and Life Satisfaction. Research and Practice in Human Resource Management, 17(1), 2435.

Armstrong, M. (2010). Essential Human resource Management Practice: A Guide To People Management. London: Kogan Page Publishers.

Azwar, S. (2016). Metode Penelitian. Yogyakarta: Pustaka Pelajar.

Bryman, A. (2016). Social Research Methods (5th ed.). London: Oxford University Press.

Dan, C., \& Seijts, G. (2016). What Engages Employees the Most or, The Ten Cs of Employee Engagement. Ivey Business Journal, 01-24.
Elnaga, A., \& Imran, A. (2013). The Effect of Training on Employee Performance. European Journal of Business and Management, 5(4), 137-147.

Flake, J. K., Pek, J., \& Hehman, E. (2017). Construct Validation in Social and Personality Research: Current Practice and Recommendation. Social Psychological and Personality Science, 8(4), 370-378. https://doi. org/10.1177/1948550617693063

Hair, F. J., Sarstedt, M., Hopkins, L., \& Kuppelwieser, V. G. (2014). Partial Least Squares Structural Equation Modeling (PLS-SEM): An Emerging Tool in Business Research. European Business Review, 26(2), 106-121. https://doi.org/10.1108/ EBR-10-2013-0128.

Hameed, S. A., \& Mohamed, N. S. (2016). HRM Practices and Organizational Performance in Hospitals. IOSR Journal of Business and Management, 18(11), 34-41.

Kline, R. B. (2015). Principles and Practice of Structural Equation Modeling. New York: Guilford Publications.

Lizote, S. A., Verdinelli, M. A., \& Nascimento, S. do. (2017). Organizational Commitment and Job Satisfaction: A Study with Municipal Civil Servants. Brazilian Journal of Public Administration, 5(16), 947967. https://doi.org/10.1590/00347612156382

Luthans, F. (2011). Organizational Behavior: An Evidence - Based Approach (12th ed.). New York: The McGraw-Hill Companies, Inc.

Maggetti, M., Gilardi, F., \& Radaelli, C. M. (2012). Statistical Research Designs for Causal Inference. In Research Design in the Social Sciences. SAGE Publications. https://doi.org/ 10.4135/9781473957664

Maryadi, H. L. P., Dewi, E. D., Aryadi, T., Santikajaya, A., Fitri, W., \& Putro, R. 
A. (2018). Kesehatan untuk Semua: Strategi Diplomasi Kesehatan Global Indonesia. Jakarta: Kementerian Luar Negeri Republik Indonesia.

Morley, L., \& Cashel, A. (2017). Collaboration in Health Care. Journal of Medical Imaging and Radiation Sciences, 48(2), 207-216. https://doi.org/10.1016/j.jmir.2017.02 .071

Muntazeri, S., \& Indrayanto, A. (2018). The Impact of Education, Training and Work Experience on Job Satisfaction and Job Performance (Study on Bank BRI Purbalingga). Journal of Accounting Management and Economics, 50(2), 50-69. Retrieved from http://jos.unsoed.ac. id/index.php/jame/article/view/1226

Pfeffer, J. (2010). Building Sustainable Organizations: The Human Factor. Academy of Management Perspectives, 24(1), 34-45. https:// doi.org/10.2139/ssrn.1545977

Pradhan, R. K., \& Jena, L. K. (2017). Employee Performance at Workplace: Conceptual Model and Empirical Validation. Business Perspectives and Research, 5(1), 69-85. https://doi.org/10.1177/22785 33716671630

Robbins, S. (2015). Essentials of Organizational Behavior (7th ed.). Upper Saddle River, New Jersey: Pearson Education, Inc.
Sahoo, C. K., \& Mishra, S. (2012). Performance Management Benefits Organizations and Their Employees. Human Resource Management International Digest, 20(6), 3-5. https://doi.org/10.1108/09670731211 260771

Sekaran, U., \& Bougie, R. (2016). Research Methods for Business: A Skill-Building Approach (7th ed.). Haddington: John Wiley \& Sons.

Sugiyono. (2016). Metode Penelitian Kuantitatif Kualitatif dan R\&D. Bandung: Alfabeta.

Vinesh. (2014). Role of Training \& Development in An Organizational Development. International Journal of Management and International Business Studies, 4(2), 213-220.

Wong, K. K.-K. (2013). Partial Least Square Structural Equation Modeling (PLS) Using Smart PLS. Marketing Bulletin, 24, 1-32. Retrieved from https://www.researchgate.net/publica tion/268449353_Partial_least_squar e_structural_equation_modeling_PL S-SEM_techniques_using_SmartPL $S$

Xiong, B., Skitmore, M., \& Xia, B. (2015). A Critical Review of Structural Equation Modeling Applications in Construction Research. Automation in Construction, 49, 59-70. https://doi.org/10.1016/j.autcon.2014 .09 .006 